Volume: 2, No. 2 | October 2015

Sukkur IBA

\title{
Impact of Dynamic Capabilities on Firm Performance: Moderating Role of Organizational Competencies
}

\author{
Khaliq ur Rehman ${ }^{\mathbf{1}}$ \\ PhD Scholar at Management Department, School of Business and Economics, \\ University of Management and Technology, Lahore Pakistan \\ Zafar Saeed $^{2}$ \\ MS Scholar at Management Department, School of Business and Economics, \\ University of Management and Technology, Lahore Pakistan
}

\begin{abstract}
This study observes the phenomenon of organizational performance with the lens of dynamic capabilities. This study investigates the impact of dynamic capabilities on organizational performance, taking organizational competencies as moderating variable, focusing on a paper industry at Lahore, Pakistan.

The measurement of dynamic capabilities is based on the multi-dimensional construct underlying the four main factors which include i.e. Sensing, Learning, strong coordination, and competitive response to the rivals. This will lead to explore relationship of dynamic capabilities with organizational performance. Empirical research posits that dynamic capabilities have a direct impact on the organizational performance of the firm. It also proves that organizational competencies have positive moderating role in relationship of organizational performance and dynamic capabilities. This suggests that the direct relationship between dynamic capabilities and performance is insignificant.
\end{abstract}

Keywords: Dynamic capabilities, Organizational competences, Organizational Performance, Sensing capabilities, Learning Capabilities, Integrating Capabilities, and Coordinating capabilities.

\section{Introduction}

The world is a global village and everything is changing rapidly. The environment of the business market becomes very dynamic. Only the best can survive and the rest will drive back home. So highlighted issue now a day for every organization is challenging to survive in such environment. The very first thing needed by all of the organization is dynamic capability so they can adjust according to the dynamic environment. (Smith \& Prietow, 2008) argued that the dynamic capabilities are those abilities which https://doi.org/10.30537/sijmb.v2i2.92

${ }^{1}$ khaliqcheema@gmail.com

2 ch.zafarsaeed@gmail.com

E-ISSN: 2410-1885; P - ISSN: 2313-1217 (C) 2015 Sukkur Institute of Business Administration - All rights reserved 
an Organization uses specially to deal with the changes in the external environment. So it enables an organization to avail opportunities when they are available and it helps to achieve an organization all the obligatory modifications in day to day operational routine and processes. Dynamic capabilities are a core element for an organization to survive in the today's dynamic environment.

According to (Eisenhardt \& Martin, 2000), dynamic capabilities are considered to be final and it does provide a basis to the firm to create sustainable competitive advantage. Thus a firm can create sustainable competitive advantage if they able to possess superior dynamic capabilities as these capabilities help the firm to create functional competences. So dynamic capabilities do have an indirect impact on the outcome of the firm (Helfat \& Peteraf, 2003). In addition, (Zott, 2003) also confirmed the indirect relation of dynamic capabilities and performance through the findings of situation analysis.

Environments today are changing and are becoming more dynamic due to the incorporation of new technology, diffusion of new practices that a firm must have to follow and due to the increasing global competition. These challenges erode the value of existing firm competences and encourage the firm to build new function competences in order to survive in the dynamic environment (Fredrickson \& Mitchell, 1984). Dynamic environments encourage the firm to respond to the changes to the environment by sensing, reallocating, reconfiguring and renewing the existing capabilities. For this, a firm must invest in its capabilities to develop that particular product.

In the last decade or so, a number of researchers was considering the concept of dynamic capacities which was to be at the heart of strategy and the methodology of the firm, firm's competitive advantage and the value creation (Eisenhardt \& Martin, 2000; Teece DJ, 1997; Winter, 2003); (Helfat et al., 2009; Teece, 2007).Hypothetical contentions have been progressed about their relationship of DC and firm performance. Existing research, however, is still stacked with ambiguous declarations and translations which have not yet been affirmed by experimental analysis. Numerous researchers are still doubtful about the part and conceptualizations progressed about dynamic capabilities (Winter, 2003; Zahra, Sapienza, \& Davidsson, 2006). So the main objective of this paper is to examine the link between dynamic capabilities, functional competence of the firm and the performance. It proposes a model which suggests that the relationship between dynamic capabilities and the performance is mediated by the functional competence of the firm. This reflects that dynamic capabilities are considered to be the antecedents which enhance the firm's functional competence which then have a positive impact on the performance. In an effort to explore this model experimentally, this paper's aim is to operationalize a composite and to operationalize the unified and combined measures of dynamic capabilities which lead to the integration of their constituent dimensions. 
In doing so, it creates and measurably tests a multi-dimensional construct which is composed and compiled of four dimensions including coordination capability, learning capabilities, integrating capabilities and firm's sensing capabilities to sense competitors and their strategic moves. By using such construct it gives the practical way for the measurement of the dynamic capabilities that could be possible by the questionnaire and the items included in the questionnaire can easily be perceived by the respondents i.e. business managers.

In this regard, the development as well as the empirical usage of a practical measurement regarding the concept of dynamic capabilities improves the toolbox of business strategic analysis. Likewise, it upgrades the perspective that such things as dynamic capacities do really exist. The literature contributed the three fold purpose. Firstly, it aims to operationalize and to measure empirically dynamic capabilities by incorporating three main dimensions by clearly identifying the distinction between dynamic capabilities and the functional capabilities; hence the notion of dynamic capabilities has been more clarified. Second, the relationship between the dynamic capabilities and performance has been explored and determined by using the data of manufacturing firms. The relationship between DC and performance seems not to be tautological as there DC had an indirect impact on the performance of the firm. The third part aims to propose the model that links Dc with the functional competences of the firm and the firm's performance.

\subsection{Objectives of the study}

This study investigates the impact of dynamic capabilities on organizational performance, and explores the moderating role of organizational competencies between the relationship of dynamic capabilities and organizational performance in paper sector of Lahore, Pakistan. More specifically the following objectives are addressed.

- To examine the impact of Dynamic capabilities on organizational performance

- To examine the moderating effect of organizational competencies in relationship of dynamic capabilities and organizational performance

\subsection{Research Questions}

To achieve the above stated objective, we formulate these research questions.

- Does dynamic capabilities impacts Organizational Performance?

- Do Organizational competencies moderate the relationship between dynamic capabilities and organizational performance?

\subsection{Significance of the study}

This study observes the phenomenon of organizational performance with the lens of dynamic capabilities. This study investigates the impact of dynamic capabilities on organizational performance, taking organizational competencies as moderating 
variable, focusing on a paper industry at Lahore, Pakistan. This is quite a unique study in its nature, because no one earlier even tried to observe the phenomenon of organizational performance of Small Medium Enterprises. Especially no investigation has been made in Paper sector of Pakistan so far.

The remainder of the paper is organized as follows: The subsequent section presents the theoretical background. The third section details the proposed model linking dynamic capabilities to Organizational performance. The fourth section describes the research methodology; the fifth section presents the data analysis and the results obtained, while the last one discusses theoretical and managerial implications and conclusion.

\section{Theoretical Background \\ 2.1. Dynamic Capabilities}

The concept of Dynamic capabilities is rooted and based on the resource based view (Wernerfelt, 1984); (Barney, 1991); (Peteraf, 1993); (Amit R, 1993); a perspective that emphasizes on the distinct resources of the firm which leads to the sustainable competitive advantage. Research scholars consider dynamic capabilities as antecedents which are the strategic routine of the firm that help to alter or change the resource base of the firm when needed; the aim is to design such value creating strategies that enhance the performance of the firm (Eisenhardt \& Martin, 2000). This suggests that the role of the dynamic capabilities is to act as a buffer mainly between the two factors that are the firm's resources and the shifting or responsive business environment by assisting the firm in terms of the adjustment of the resource base so to create and sustain the competitive advantage. So, the resource-based view on one hand focuses on the choice of the resources choice, the dynamic capabilities view on the other hand emphasize on the development of the resources as well as its renewal., (Amit R, 1993) define the notion 'capabilities' as the ability of the firm to exploit its resources as well as integrates or combines its resources by its organizational routines for the purpose of achieving its target.

(Kogut \& Zander, 1992) utilize the term 'combinative capacities' to refer mainly to the organizational procedures by which firms obtain and incorporate learning assets or knowledge resources which result in the creation of new applications by combining of all those resources. While the estimation of the thought of dynamic abilities is still tested by a few researchers, there is by all accounts a rising accord in the literature that they vary from operational capabilities or from the functional competences by emphasizing on the concept of change (Winter, 2003).

\subsection{Types of Capabilities}

\subsubsection{Integration Capability}

Integration capacities are the capabilities of the firm to evaluate the worth of their resources already available and integrating them in order to shape new competencies (Iansiti \& Clark, 1994); (Amit R, 1993). Along with this, the operation of the new 
configurations or outline of the functional competencies rests in two things; first one being the effective organization of all the tasks in hand and second one being the synchronization or organization of all of the activities active (Collis, 1994); (Helfat \& Peteraf, 2003). The processes of coordination link as well as interface single routes through a variety of process like communication, assigning of the tasks, scheduling, etc. (Teece DJ, 1997) proposes the deficiency of the above elements, proper coordination and the combination of the variety of numerous resources, and tells us the reason behind the devastating effects on the competitive position of the incumbent firms when there are minor changes or variations in technology. Like (R. M. Henderson \& Clark, 1990), in photolithographic industry, have actually shown the shattering impression of trivial innovations on the incumbent firms and these actually had a huge impact on the way the systems required configuration. Their debate is on these innovations which are systematic or architectural, that they require proper coordination as well as integration of various engineering tasks. The capability of learning cannot be comprehended as a primary means of achieving the strategic renewal.

\subsubsection{Coordinating Capabilities}

To realize the Coordination procedures is considered to be significant by the management of the firm. Coordination capabilities help the firm to integrate all the tacit knowledge as well as codified knowledge in order to produce and deliver those products that are cost effective and get more information and data about the needs and demands of the customers (Helfat \& Raubitschek, 2000).

Coordination capabilities serves for the development of new product where cross functional team composed of different departments works together to design any particular product e.g. (Clark \& Fujimoto, 1991; G. D., 1988; Dougherty, 1992; Helfat \& Raubitschek, 2000).

\subsubsection{Learning Capabilities}

In order to achieve this renewal, the organizations are required to find out and learn innovative ways along with being able to exploit the things which they have learned in the past.(March, 1991). (Teece DJ, 1997) debate that learning is a vital process and by investigations and doing repetition, the results would be impressive as problems would be solved in an appropriate manner and this would also help the firms in the identification of the new ways or opportunities of production. The processes of learning are very dynamic. Even though the individuals might get the innovative ideas, those ideas are then actually shared within the context of the organization and at the same time some of those ideas become the artifacts of organization. Strategic competitive response capability extends the definition and concept of dynamic capabilities proposed by (Eisenhardt \& Martin, 2000) in order to include or embrace the formation of market change along with the response to exogenous change (Helfat et al., 2009). 
Learning procedures or process that aim to enhance and advance technological knowledge is critically significant for sustainable competitive advantage; particularly in the pharmaceutical industries or it can enhance such industries like semiconductors (Bogner WC, 1994; Helfat, 1997; R. Henderson \& Cockburn, 1994). In addition to that, sharing knowledge as well as the creation of cross cultural teams would result in the combination of that knowledge that is novel or new. The reason is that the cross functional teams engage employees to interact with each other who belongs to different functional department and that leads to the recombination or renewal of technological as well as marketing competences. Moreover, job rotation fosters the process of absorption of knowledge more effectively (Cohen \& Levinthal, 1990).

\subsubsection{Sensing Capabilities}

This ability can be conceptualized as the capability of the firm to detect new opportunities, scan environment, answer to competitive planned moves and evaluates the competitive position. Even though if an established organization gets to know about the change need to address the requirements of the environment, still it is not easy for them to respond properly. Let's take the example of an empirical research. It clearly provides proofs that minor technology shifts related changes are not easy to be handled precisely (R. M. Henderson \& Clark, 1990; Tushman \& Anderson, 1986). The most important thing however is the ability to know and respond effectively to the environmental changes. So basically what encourage change within a firm are strategic competitive response and the way of coordination. Like this, they may add to a better understanding and measurement of the compound concept of dynamic capabilities.

Dynamic capabilities have been troubled by few problems related to their operations, explanations and by their expected terms with the performance of the organization. There are however some proofs which show that performance of an organization can be affected by its dynamic capabilities (R. Henderson \& Cockburn, 1994) provides evidence that capability of the firm to mix information from an outside source has positive impacts to its research productivity. (Singh \& Zollo, 1998) confirms that acquirers who focused more on organizing their integration procedures come up with better and more productive performance comparative to their competitors. (Deeds, DeCarolis, \& Coombs, 2000) proves that dynamic capabilities like the process of forming alliance is considerably related to the number of products that are developed newly in biotechnology area.

The firm must have the ability to reshape its resource base by sensing the changes in the environment effectively and respond accordingly. If a firm has the ability to be responsive to the changes of the environment including analyzing the competition, ii would have a positive impact on redefining the marketing as well as technological competences which lead to the redefining and renewal of the product portfolio. Last, the flexibility of the firm in terms of being responsive to the changes in the environment is also linked with the organizational structure that a firm is following 
which is decentralized structure. If a firm doesn't possess dynamic capabilities, it would restrain to seek the renewal opportunities.

\subsection{Organizational Competencies}

Organizational competences are depicted as the purposive combinations of all the assets or resources that empower an association to perform operational exercises or activities, for example, logistics, promoting and deals and assembling or manufacturing. The archetypical firm equipped with competences/resources but lacking dynamic capabilities will, in equilibrium, earn "it's living by producing and selling the same product, on the same scale and to the same customer population over time"(Winter, 2003). Dynamic capabilities on the other hand emphasize on the renewal of the functional competence which is the source of sustainable competitive advantage. DC are also referred as a complex routines by some scholars (Zollo \& Winter, 2002), some scholars are of the view that the existence of DC has taken for granted by ignoring the main processes that results in the creation and formation of these capabilities (Galunic \& Eisenhardt, 2001).

Organizational competencies are of two kinds. One division is made on the basis of marketing capabilities and the second one is technical competencies. When talking about the marketing competence, it helps the firm to understand the basic needs and wants of the customers, to identify the new customers and to analyze as well as respond to the competition (Fowler, King, Marsh, \& Victor, 2000). This shows that marketing competences is a key driver that enhances the performance of the firm (Day, 1994). Technological competencies serve a firm to engage in a problem solving process as well as implementing and creating or developing the new prototypes and to absorb knowledge from the environment that is from outside the firm (L.-B. D., 1995). Firms that are not able to advance their technological capabilities are not able to compete and hence cannot be able to achieve the commercial success (Fowler et al., 2000).

(Eisenhardt \& Martin, 2000), responded to the above criticism by commenting that dynamic capability processes have been comprised of "precise and identifiable or exclusive routines" which have been researched. Mainly, they suggest that the use of the several processes can be taken as examples of dynamic capabilities for instance, product development, and the process of strategic decision making reallocation and renewal of the routines. This paper mainly recognizes three dimensions: facilitating/coordination of the activities, learning and key aggressive reaction or competitive response.

\subsection{Organizational Performance}

There are a few studies that investigate the direct relation of DC and its impact on performance. David (Collis, 1994) define Dynamic capabilities as a higher- order capabilities and suggest that DC aims a firm to avoid or ignore path dependencies that are particularly imposed by the competencies that are at lower level. So a firm must have to reconfigure its resources and aim to continual renewal of the new resources in SIJMB $P$ - ISSN: 2313-1217 E-ISSN: 2410-1885 @ 2015 Sukkur Institute of Business Administration V.2, No.2 |Oct 15 
order to attain the sustainable competitive advantage.(Eisenhardt \& Martin, 2000) is of the same view and suggest that DC is distinct as well as valuable, moreover DC is considered to be equi-final and that are inimitable which shows its uniqueness and hence not easy to copy. It suggests that DC alone is not results in creating the sustainable competitive advantage rather it results in the contribution of firm's superior performance. In nutshell, DC aim to create and reconfigure resource base (Eisenhardt \& Martin, 2000), zero-order capabilities (Winter, 2003) as well as operational capabilities, and thus have an impact on performance. This shows that there exist an indirect link between DC and performance. The phenomenon of DC and its impact on performance is not clear and hence not well understood (Zott, 2003).

\subsection{Dynamic Capabilities in SME's}

Innovation is one of the most fundamental processes underpinning economic growth. The role of innovation in SMEs that drives and influences on innovation performance which makes a distinction between a few very high-performance new and small firms that can have a disproportionate effect on innovation, often by introducing breakthrough innovations to the market. In this study we present dynamic capabilities that facilitate innovative strategies (proactive-creativity strategy and growth-risk orientation) in Small- and Medium-sized Enterprises (SMEs). Corporate entrepreneurship is seen as the integration of opportunity-seeking and advantageseeking actions providing new, valuable and unique business concepts. We build upon the Resource-Based View (RBV) of the firm and in particular elaborate on the accumulation of dynamic capabilities contributing to innovation .We develop four categories of dynamic capabilities that are critical for the SMEs entrepreneurial position: internal and external reconfiguration and integration capabilities, resource acquisition capability, learning network capabilities and strategic path aligning capabilities. Most of the relations are medium to highly statistical significant for dynamic capabilities relationships with innovative strategies.

In Dynamic capabilities and entrepreneurial team development in SMEs by DonatoIacobucci Entrepreneurial companies create, define, discover, and exploit opportunities frequently well ahead of their rivals. A key outcome of the entrepreneurial process is a new business creation. Most new businesses employ only one or very few persons. The emergent literature on dynamic capabilities and their role in value creation are riddled with inconsistencies, overlapping definitions, and outright contradictions. Yet, the theoretical and practical importance of developing and applying dynamic capabilities to sustain a firm's competitive advantage in complex and volatile external environments has catapulted this issue to the forefront of the research agenda of many scholars. In this paper, we offer a definition of dynamic capabilities, separating them from substantive capabilities as well as from their antecedents and consequences.

\section{Theoretical Framework and Hypothesis}


Keeping in view a hierarchical view of DC a new model has been proposed which suggests that DC serves not only as acquiring the resources but also serves as to reconfigure the lower level competences of the firm. So this model takes organizational competencies as moderating variable, that means organizational competencies enhances the intensity of dynamic capabilities to achieve superior organizational performance. The relationship and impact of predominant firm's capabilities on its overall performance has been widely examined and studied in the literature. The aim of this paper is to emphasize mainly on the role of organizational competences, which empower firms to perform viably their everyday exercises with respect to competition prevailing in the market (Danneels, 2000; Song, Droge, Hanvanich, \& Calantone, 2005).

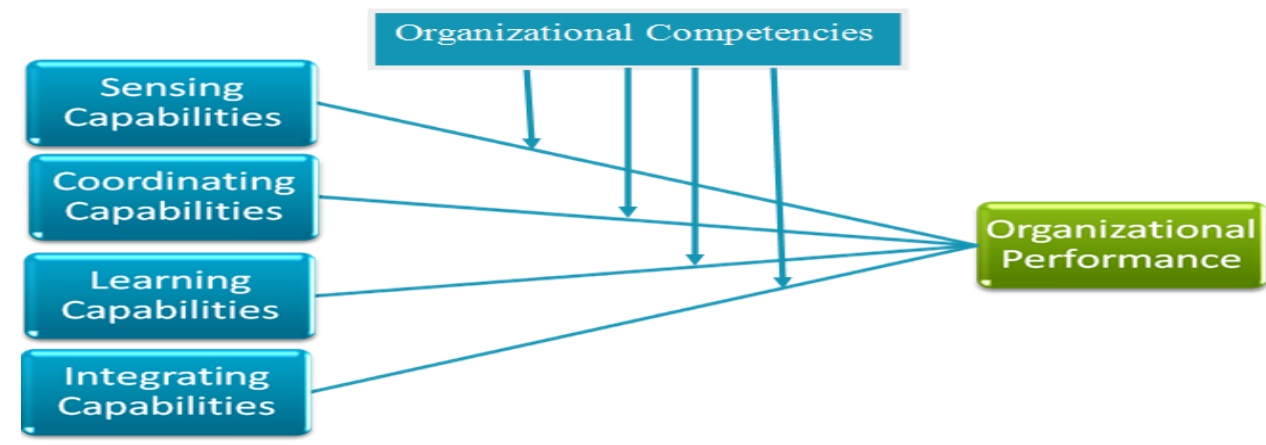

Figure 1: Theoretical Framework

For the theoretical framework of this study, Dynamic abilities have been defined as higher-request skills that permit firms to endeavor or to exploit lower-request capabilities that exist in the organization, and all the more significantly to identify as well as recognize the new innovative technological capabilities and marketing capabilities. Higher order capabilities must be developed by the firms because it fosters the process of learning which results in the leveraging of all the firm's resources. Moreover, Dynamic capabilities do eliminate the impact of path dependencies. The exploitation of existing resources would not result in creating the competitive advantage of the firm. But if a firm possesses superior dynamic capabilities then they would able to create functional competences more effectively and faster relative to its rivals. However, if a firm has some of superior competences, they will not able to respond to the changes in the environment effectively.

Above proposed model and the debate lead this study towards the hypothesis stage. In light of above discussion, these are the hypothesis that this study will be able to prove or disprove.

H1: Dynamic Capabilities have Impact on Organizational Performance. 
As dynamic capabilities have four types (ingredients), so we are supposed to develop sub hypothesis.

H1 (a): Sensing Capability has influence on organizational Performance.

H1 (b): Learning Capability has influence on organizational Performance.

H1(c): Integrating Capability has influence on organizational Performance.

H1 (d): Coordinating Capability has influence on organizational Performance.

$\mathbf{H}$ 2: Organizational Competencies have moderating role in relation of Dynamic Capabilities and Organizational Performance

As dynamic capabilities have four types (ingredients) so we are supposed to develop sub hypothesis.

H2 (a): Organizational Competencies have moderating role in relation to Sensing Capabilities and Organizational Performance

H2 (b): Organizational Competencies have moderating role in relation to Learning Capabilities and Organizational Performance

$\mathbf{H 2}$ (c): Organizational Competencies have moderating role in relation to Integrating Capabilities and Organizational Performance

H2 (d): Organizational Competencies have moderating role in relation to Coordinating Capabilities and Organizational Performance

\section{Methodology}

\subsection{Participants and setting of Research}

This study was conducted in Paper sector that is contributor towards economy of Pakistan, which consist of five medium level organizations, and forty small organizations working in Lahore. Data was collected through self-administrated questionnaire. Participants of the survey were professionals and top and middle level managers who were responsible for implementing the strategies about the production, new product development, and selling, promotional, and pricing strategies. Response rate of this study was about $80 \%$ as 130 professionals were selected and questionnaires were distributed to them, but only 104 participants took part actively in this study.

\subsection{Construct Measurement}

All the variables of this study were measured by the professional responses to the instrument that was used in this study. All the items were measured on five point Likert-Scale having range from Strongly Agree to Strongly Disagree. Complete range of measure was discussed under findings including Cronbach's Alpha, Descriptive Statistics, Correlation, and Regression Analysis.

\subsubsection{Dynamic Capabilities}

For Dynamic Capabilities we adopt the items from the questionnaires developed and tested by (Teece DJ, 1997) having alpha value (.692). This measure consists of 4 
dimensions like "Sensing Capabilities", "Learning Capabilities", "Integrating Capabilities", and "Coordinating Capabilities".

\subsubsection{Organizational Performance}

To Measure Organizational Performance, we adopt items from (Khuram Shahzad, 2014) having alpha value (.693) that consist of 11 items

\subsubsection{Organizational Competencies}

Organizational Competencies were measured on a six-dimensional scale and the reliability of those six items (.695).

\section{Findings}

\subsection{Reliability}

\begin{tabular}{|c|c|}
\hline \multicolumn{2}{|l|}{ Reliability Statistics of overall Instrument } \\
\hline Cronbach's Alpha & N of Items \\
\hline .700 & $\underline{33}$ \\
\hline \multicolumn{2}{|l|}{ Item-Wise Reliability Statistics } \\
\hline Determinants & $\underline{\text { Cronbach's }}$ \\
\hline & Alpha \\
\hline Sensing Capabilities (SC) & 0.694 \\
\hline $\begin{array}{l}\text { We frequently scan the environment to identify new business } \\
\text { opportunities. }\end{array}$ & 683 \\
\hline $\begin{array}{l}\text { We periodically review the likely effect of changes in our business } \\
\text { environment on customers. }\end{array}$ & .705 \\
\hline $\begin{array}{l}\text { We often review our product development efforts to ensure they are in } \\
\text { line with what the customers want. }\end{array}$ & .682 \\
\hline $\begin{array}{l}\text { We devote a lot of time implementing ideas for new products and } \\
\text { improving our existing products. }\end{array}$ & .708 \\
\hline Learning Capabilities (LC) & 0.698 \\
\hline $\begin{array}{l}\text { We have effective routines to identify, value, and impart new } \\
\text { information and knowledge. }\end{array}$ & .680 \\
\hline $\begin{array}{l}\text { We have adequate routines to assimilate new information and } \\
\text { knowledge. }\end{array}$ & .715 \\
\hline $\begin{array}{l}\text { We are effective in transforming existing information into new } \\
\text { knowledge. }\end{array}$ & .685 \\
\hline We are effective in utilizing knowledge into new products. & 697 \\
\hline $\begin{array}{l}\text { We are effective in developing new knowledge that has the potential to } \\
\text { influence product development }\end{array}$ & .716 \\
\hline Integrating Capabilities (IC) & 0.696 \\
\hline We are forthcoming in contributing our individual input to the group. & 697 \\
\hline $\begin{array}{l}\text { We have a global understanding of each other's tasks and } \\
\text { responsibilities. }\end{array}$ & 698 \\
\hline We carefully inter-relate our actions to each other to meet changing & .705 \\
\hline
\end{tabular}

SIJMB $P$ - ISSN: 2313-1217 E-ISSN: 2410-1885 @ 2015 Sukkur Institute of Business Administration V.2, No.2 |Oct 15 
conditions.

Group members manage to successfully interconnect their activities. $\quad .686$

Coordinating Capabilities (CC)

We ensure that the output of our work is synchronized with the work of $\quad .669$

others.

We ensure an appropriate allocation of resources (e.g., information,

time, reports) within our group.

Group members are assigned to tasks commensurate with their task-

relevant knowledge and skills.

Overall, our group is well coordinated.

Organizational Performance (OP)

Quality of your company's products/services compared with

competitors, is

Level of your customers' satisfaction compared with competitors, is

Technological developments in your company compared with

competitors, are

Profitability of your company compared with competitors, is

Sales growth in your company compared with competitors, is

Your company's "Returns on Investment" compared with competitors,

Your company's market share compared with competitors, is

New products launched by your company compared with competitors, are

Overall growth of your company compared with competitors, is

Image of your company in market compared with competitors, is

Our organization believes in having co-operation with universities and other research institutes to be competitive in market.

Organizational Competencies (OC)

Our Organization has a very strong brand name among its competitors. $\quad .683$

Our Organization put its emphasis to build strong sales force. $\quad .705$

Our organization has well-organized marketing department. $\quad .681$

$\begin{array}{ll}\text { Our organization believes in continuous adaptation of new } & .709\end{array}$

manufacturing technology.

Our organization has very strong R\&D department, and organization $\quad .680$

spend a lot on R\&D

Our organization believes in having co-operation with universities and other research institutes to be competitive in market.

\subsection{Correlation}

\begin{tabular}{llllll}
\hline & \multicolumn{5}{c}{ Correlations Matrix } \\
\hline LC & Pearson Correlation & $\underline{\text { SC }}$ & $\frac{\text { LC }}{167}$ & $\underline{\text { IC }}$ & $\underline{\text { CC }}$ \\
\hline
\end{tabular}

SIJMB $P$ - ISSN: 2313-1217 E-ISSN: 2410-1885 @ 2015 Sukkur Institute of Business Administration V.2, No.2 |Oct 15 
Khaliq \& Zafar / Impact of Dynamic Capabilities on Firm Performance: Moderating Role of Organizational

\begin{tabular}{llllll}
\hline & & & & & \\
\hline & Sig. (2-tailed) & .090 & & & \\
& $\mathrm{~N}$ & 104 & 104 & & \\
$\mathrm{IC}$ & Pearson Correlation & $.473^{* *}$ & $.416^{* *}$ & 1 & \\
& Sig. (2-tailed) & .000 & .000 & & \\
& $\mathrm{~N}$ & 104 & 104 & 104 & \\
$\mathrm{CC}$ & Pearson Correlation & $.220^{*}$ & $.672^{* *}$ & .179 & 1 \\
& Sig. (2-tailed) & .025 & .000 & .069 & \\
& $\mathrm{~N}$ & 104 & 104 & 104 & 104 \\
OP & Pearson Correlation & $.420^{* *}$ & .083 & $.529^{* *}$ & .129 \\
& Sig. (2-tailed) & .000 & .000 & .000 & .192 \\
& $\mathrm{~N}$ & 104 & 104 & 104 & 104 \\
\hline
\end{tabular}

$* *$ Correlation is significant at the 0.01 level (2-tailed).

*Correlation is significant at the 0.05 level (2-tailed).

To determine the relationship between dynamic capabilities and organizational performance Pearson correlation test was used. Above mentioned table indicates that each type of organizational capabilities has positive relationship with organizational performance. Dramatically, Learning capabilities and coordinating capabilities have weak but positive relationship with organizational performance.

\subsection{Regression}

Regression Analysis for Sensing Capabilities and Organizational Performance

\begin{tabular}{|c|c|c|c|c|}
\hline \multicolumn{5}{|c|}{ Model Summary } \\
\hline Model & $\underline{\mathrm{R}}$ & $\underline{\text { R Square }}$ & Adjusted R Square & $\underline{\text { Std. Error of the Estimate }}$ \\
\hline 1 & $.420^{\mathrm{a}}$ & .176 & .168 & .229 \\
\hline a. Pred & s: (Con & tant), SC & & \\
\hline
\end{tabular}

\begin{tabular}{|c|c|c|c|c|c|c|}
\hline \multicolumn{7}{|c|}{ ANOVA $^{a}$} \\
\hline & & $\underline{\text { Sum of Squares }}$ & $\underline{\mathrm{df}}$ & $\begin{array}{l}\text { Mean } \\
\text { Square }\end{array}$ & $\underline{F}$ & Sig. \\
\hline \multirow[t]{3}{*}{1} & Regression & 1.147 & 1 & 1.147 & 21.860 & $.000^{\mathrm{b}}$ \\
\hline & Residual & 5.350 & 102 & .052 & & \\
\hline & Total & 6.497 & 103 & & & \\
\hline \multicolumn{7}{|c|}{$\begin{array}{l}\text { a. Dependent Variable: OP } \\
\text { b. Predictors: (Constant), SC }\end{array}$} \\
\hline \multicolumn{7}{|c|}{ Coefficients $^{\mathrm{a}}$} \\
\hline \multicolumn{2}{|c|}{ Model } & $\begin{array}{l}\text { Un-standardized } \\
\text { Coefficients }\end{array}$ & & $\frac{\text { Standardized }}{\text { Coefficients }}$ & $\underline{\mathrm{t}}$ & Sig. \\
\hline
\end{tabular}


Khaliq \& Zafar / Impact of Dynamic Capabilities on Firm Performance: Moderating Role of Organizational

\begin{tabular}{llllllll}
\hline & & & & & \\
\hline & & B & Std. & Beta \\
& & Error & & & \\
1 & (Constant) & 2.876 & .278 & & 10.359 & .000 \\
& SC & .319 & .068 & .420 & 4.675 & .000
\end{tabular}

a. Dependent Variable: OP

To analyze the influence of Sensing Capabilities (SC) on Organizational Performance, we use regression analysis .Finding shows that the Organizational Performance is moderately dependent on sensing capabilities of the organization. As table shows that value of R square is 0.176 for Sensing Capabilities (SC) and Organizational Performance. Hence we can say that we have become able to prove our H1 (a) hypothesis.

Regression Analysis for Sensing Capabilities and Organizational Performance with moderating effect of Organizational Competencies

\begin{tabular}{|c|c|c|c|c|}
\hline \multicolumn{5}{|c|}{ Model Summary } \\
\hline Model & $\underline{\mathrm{R}}$ & $\underline{\text { R Square }}$ & Adjusted R Square & $\frac{\text { Std. Error of the }}{\text { Estimate }}$ \\
\hline 1 & $.475^{\mathrm{a}}$ & .225 & .218 & .222 \\
\hline a. Predi & (Co & Interacti & & \\
\hline
\end{tabular}

\begin{tabular}{|c|c|c|c|c|c|c|}
\hline \multicolumn{7}{|c|}{ ANOVA $^{a}$} \\
\hline Model & & $\begin{array}{l}\text { Sum of } \\
\underline{\text { Squares }}\end{array}$ & $\underline{\mathrm{df}}$ & Mean Square & $\underline{F}$ & $\underline{\text { Sig. }}$ \\
\hline 1 & Regression & 1.464 & 1 & 1.464 & 29.676 & $.000^{\mathrm{b}}$ \\
\hline & $\begin{array}{l}\text { Residual } \\
\text { Total }\end{array}$ & $\begin{array}{l}5.033 \\
6.497\end{array}$ & $\begin{array}{l}102 \\
103\end{array}$ & .049 & & \\
\hline
\end{tabular}

a. Dependent Variable: OP

b. Predictors: (Constant), Interaction1

\begin{tabular}{|c|c|c|c|c|c|c|}
\hline \multicolumn{7}{|c|}{ Coefficients $^{\mathrm{a}}$} \\
\hline \multirow[t]{2}{*}{ Mode } & & \multicolumn{2}{|c|}{$\begin{array}{l}\text { Un-standardized } \\
\text { Coefficients }\end{array}$} & $\begin{array}{l}\frac{\text { Standardized }}{\text { Coefficients }} \\
\end{array}$ & $\underline{\mathrm{t}}$ & $\underline{\text { Sig. }}$ \\
\hline & & B & Std. Error & Beta & & \\
\hline 1 & (Constant) & 3.266 & .167 & & 19.526 & .000 \\
\hline
\end{tabular}

SIJMB $P$ - ISSN: 2313-1217 E-ISSN: 2410-1885 @ 2015 Sukkur Institute of Business Administration V.2, No.2 |Oct 15 
Khaliq \& Zafar / Impact of Dynamic Capabilities on Firm Performance: Moderating Role of Organizational

$\begin{array}{llllll}\text { Interaction1 } & .054 & .010 & .475 & 5.448 & .000\end{array}$

a. Dependent Variable: OP

To check the moderating role of organizational competencies between relationship of organizational performance and sensing capabilities, we add an interaction term and regress it with organizational performance. Table indicates that organizational competencies do moderate, and positively moderates the relationship between organizational performance and sensing capabilities. As the value of $\mathrm{R}$ square has increased to 0.225 from 0.176 . Hence $\mathrm{H} 2$ (a) Hypothesis has also proved.

Regression Analysis for Learning Capabilities and Organizational Performance

\begin{tabular}{|c|c|c|c|c|}
\hline \multicolumn{5}{|c|}{ Model Summary } \\
\hline$\underline{\text { Model }}$ & $\underline{\mathrm{R}}$ & $\underline{\mathrm{R} \text { Square }}$ & Adjusted R Square & $\underline{\text { Std. Error of the Estimate }}$ \\
\hline 1 & $.083^{\mathrm{a}}$ & .007 & -.003 & .251 \\
\hline
\end{tabular}

a. Predictors: (Constant), LC

\begin{tabular}{|c|c|c|c|c|c|c|}
\hline \multicolumn{7}{|c|}{ ANOVA $^{a}$} \\
\hline & Model & $\begin{array}{l}\text { Sum of } \\
\text { Squares }\end{array}$ & $\underline{\mathrm{df}}$ & Mean Square & $\underline{F}$ & Sig. \\
\hline \multirow[t]{3}{*}{1} & Regression & .045 & 1 & .045 & .715 & $.400^{\mathrm{b}}$ \\
\hline & Residual & 6.452 & 102 & .063 & & \\
\hline & Total & 6.497 & 103 & & & \\
\hline \multicolumn{7}{|c|}{ a. Dependent Variable: OP } \\
\hline \multicolumn{7}{|c|}{ b. Predictors: (Constant), LC } \\
\hline
\end{tabular}

\begin{tabular}{|c|c|c|c|c|c|c|}
\hline \multicolumn{7}{|c|}{ Coefficients $^{\mathrm{a}}$} \\
\hline \multicolumn{2}{|r|}{$\underline{\text { Model }}$} & \multicolumn{2}{|c|}{$\frac{\text { Un-standardized }}{\underline{\text { Coefficients }}}$} & $\frac{\text { Standardized }}{\text { Coefficients }}$ & $\underline{\mathrm{t}}$ & $\underline{\text { Sig. }}$ \\
\hline & & B & $\begin{array}{l}\text { Std. } \\
\text { Error }\end{array}$ & Beta & & \\
\hline 1 & (Constant) & 4.423 & .301 & & 14.700 & .000 \\
\hline a. D & $\begin{array}{c}\text { LC } \\
\text { endent Varia }\end{array}$ & $\begin{array}{l}-.062 \\
\text { OP }\end{array}$ & .074 & -.083 & -.846 & .400 \\
\hline
\end{tabular}

SIJMB $P$ - ISSN: 2313-1217 E-ISSN: 2410-1885 @ 2015 Sukkur Institute of Business Administration V.2, No.2 |Oct 15 
To analyze the influence of Learning Capabilities (LC) on Organizational Performance, we use regression analysis .Finding shows that the Organizational Performance is slightly dependent on learning capabilities of the organization. As table shows that value of $\mathrm{R}$ square is 0.007 for learning Capabilities (LC) and Organizational Performance. Hence H 1 (b) hypothesis also proved.

Regression Analysis for Sensing Capabilities and Organizational Performance with moderating effect of Organizational Competencies

\begin{tabular}{cccccc}
\hline \multicolumn{5}{l}{} & \multicolumn{3}{c}{ Model Summary } \\
\hline$\underline{\text { Model }}$ & $\underline{\mathrm{R}}$ & $\underline{\mathrm{R} \text { Square }}$ & $\underline{\text { Adjusted R Square }}$ & $\underline{\text { Std. Error of the Estimate }}$ \\
1 & $.213^{\mathrm{a}}$ & .046 & & .036 & .247 \\
\multicolumn{2}{l}{ a. Predictors: (Constant), Interaction2 } & & \\
\hline
\end{tabular}

\begin{tabular}{|c|c|c|c|c|c|c|}
\hline \multicolumn{7}{|c|}{ ANOVA $^{\mathrm{a}}$} \\
\hline & $\underline{\text { Model }}$ & $\begin{array}{l}\text { Sum of } \\
\text { Squares }\end{array}$ & $\underline{\mathrm{df}}$ & $\underline{\underline{\text { Mean }}}$ & $\underline{F}$ & Sig. \\
\hline \multirow[t]{3}{*}{1} & Regression & .296 & 1 & .296 & 4.866 & $.030^{\mathrm{b}}$ \\
\hline & Residual & 6.201 & 102 & .061 & & \\
\hline & Total & 6.497 & 103 & & & \\
\hline \multicolumn{7}{|c|}{ a. Dependent Variable: OP } \\
\hline \multicolumn{7}{|c|}{ b. Predictors: (Constant), Interaction2 } \\
\hline
\end{tabular}

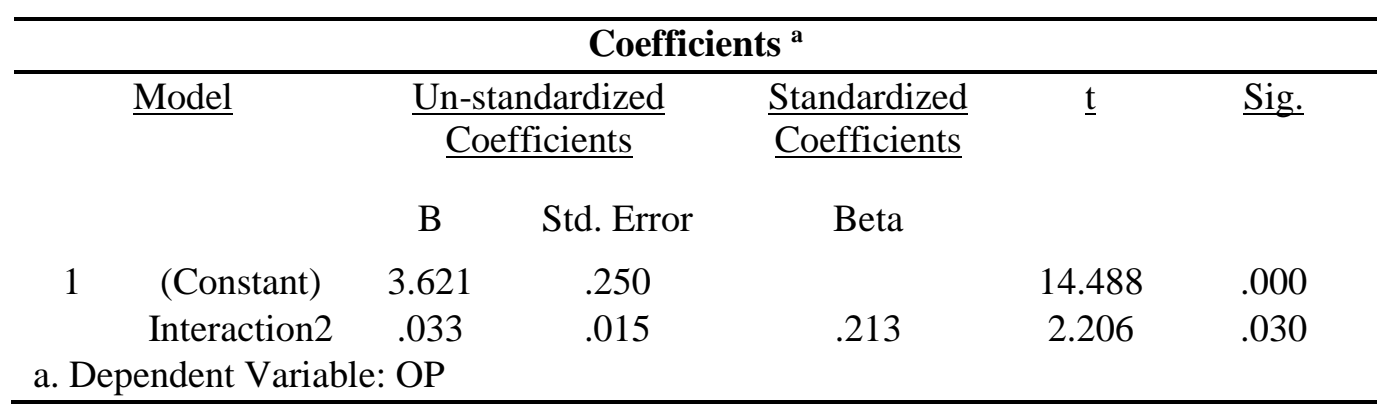

To check the moderating role of organizational competencies between relationship of organizational performance and learning capabilities, we add an interaction term and regress it to an organizational performance. Table indicates that organizational competencies does moderates, and positively moderates the relationship between 
organizational performance and learning capabilities. As the value of $\mathrm{R}$ square has increased to 0.046 from 0.007 . Hence $\mathrm{H} 2$ (b) Hypothesis has also proved.

Regression Analysis for Integrating Capabilities and Organizational Performance

\begin{tabular}{|c|c|c|c|c|}
\hline \multicolumn{5}{|c|}{ Model Summary } \\
\hline Model & $\underline{\mathrm{R}}$ & $\underline{\text { R Square }}$ & $\frac{\text { Adjusted R }}{\text { Square }}$ & $\underline{\text { Std. Error of the Estimate }}$ \\
\hline 1 & $.529^{\mathrm{a}}$ & .280 & .273 & .214 \\
\hline a. Predic & Con & , IC & & \\
\hline
\end{tabular}

\begin{tabular}{|c|c|c|c|c|c|c|}
\hline \multicolumn{7}{|c|}{ ANOVA $^{a}$} \\
\hline & Model & $\underline{\text { Sum of Squares }}$ & $\underline{\mathrm{df}}$ & Mean Square & $\underline{F}$ & Sig. \\
\hline \multirow[t]{3}{*}{1} & Regression & 1.820 & 1 & 1.820 & 39.704 & $.000^{\mathrm{b}}$ \\
\hline & Residual & 4.676 & 102 & .046 & & \\
\hline & Total & 6.497 & 103 & & & \\
\hline \multicolumn{7}{|c|}{$\begin{array}{l}\text { a. Dependent Variable: OP } \\
\text { b. Predictors: (Constant), IC }\end{array}$} \\
\hline
\end{tabular}

\begin{tabular}{|c|c|c|c|c|c|c|}
\hline \multicolumn{7}{|c|}{ Coefficients $^{\text {a }}$} \\
\hline \multicolumn{2}{|c|}{ Model } & \multicolumn{2}{|c|}{$\frac{\text { Un-standardized }}{\text { Coefficients }}$} & \multirow{2}{*}{$\frac{\frac{\text { Standardized }}{\text { Coefficients }}}{\text { Beta }}$} & \multirow[t]{2}{*}{$\underline{t}$} & \multirow[t]{2}{*}{ Sig. } \\
\hline \multirow{3}{*}{1} & & B & $\begin{array}{l}\text { Std. } \\
\text { Error }\end{array}$ & & & \\
\hline & (Constant) & 1.118 & .485 & & 2.305 & .023 \\
\hline & IC & .737 & .117 & .529 & 6.301 & .000 \\
\hline a. D & endent Varia & & & & & \\
\hline
\end{tabular}

To analyze the influence of Integrating Capabilities (IC) on Organizational Performance, we use regression analysis .Finding shows that the Organizational Performance is moderately dependent on integrating capabilities of the organization. As table shows that value of $\mathrm{R}$ square is 0.280 for Integrating Capabilities (IC) and Organizational Performance. Hence H 1 (c) hypothesis has also proved.

Regression Analysis for Integrating Capabilities and Organizational Performance with moderating effect of Organizational Competencies

\begin{tabular}{lllll}
\hline \multicolumn{5}{c}{ Model Summary } \\
\hline$\underline{\text { Model }}$ & $\underline{\mathrm{R}}$ & $\underline{\mathrm{R} \text { Square }}$ & $\underline{\text { Adjusted R Square }}$ & $\underline{\text { Std. Error of the Estimate }}$ \\
\hline
\end{tabular}


Khaliq \& Zafar / Impact of Dynamic Capabilities on Firm Performance: Moderating Role of Organizational

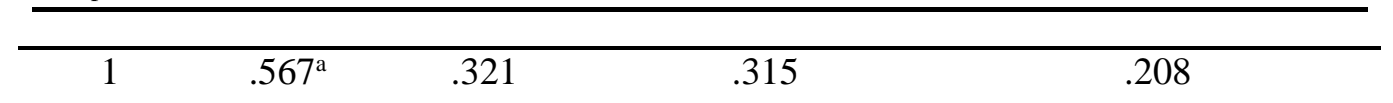

a. Predictors: (Constant), Interaction3

\begin{tabular}{|c|c|c|c|c|c|c|}
\hline \multicolumn{7}{|c|}{ ANOVA $^{\mathrm{a}}$} \\
\hline & $\underline{\text { Model }}$ & $\begin{array}{l}\underline{\text { Sum of }} \\
\text { Squares }\end{array}$ & $\underline{\mathrm{df}}$ & $\underline{\text { Mean Square }}$ & $\underline{F}$ & $\underline{\text { Sig. }}$ \\
\hline \multirow[t]{3}{*}{1} & Regression & 2.087 & 1 & 2.087 & 48.279 & $.000^{\mathrm{b}}$ \\
\hline & Residual & 4.410 & 102 & .043 & & \\
\hline & Total & 6.497 & 103 & & & \\
\hline \multicolumn{7}{|c|}{ b. Predictors: (Constant), Interaction3 } \\
\hline
\end{tabular}

\begin{tabular}{|c|c|c|c|c|c|c|}
\hline \multicolumn{7}{|c|}{ Coefficients $^{\text {a }}$} \\
\hline \multirow{3}{*}{1} & $\underline{\text { Model }}$ & \multicolumn{2}{|c|}{$\frac{\text { Un-standardized }}{\text { Coefficients }}$} & \multirow{2}{*}{$\frac{\frac{\text { Standardized }}{\text { Coefficients }}}{\text { Beta }}$} & \multirow{2}{*}{$\begin{array}{c}\underline{\mathrm{t}} \\
11.892\end{array}$} & \multirow{2}{*}{$\begin{array}{l}\text { Sig. } \\
.000\end{array}$} \\
\hline & (Constant) & $\begin{array}{c}\mathrm{B} \\
2.636\end{array}$ & $\begin{array}{l}\text { Std. Error } \\
.222\end{array}$ & & & \\
\hline & Interaction 3 & .091 & .013 & .567 & 6.948 & .000 \\
\hline \multicolumn{4}{|c|}{ a. Dependent Variable: OP } & & & \\
\hline
\end{tabular}

To check the moderating role of organizational competencies between relationship of organizational performance and integrating capabilities, we add an interaction term and regress it to an organizational performance. Table indicates that organizational competencies does moderates, and positively moderates the relationship between organizational performance and integrating capabilities. As the value of $\mathrm{R}$ square has increased to 0.321 from 0.280 . Hence $\mathrm{H} 2$ (c) Hypothesis has also proved.

Regression Analysis for Coordinating Capabilities and Organizational Performance

\begin{tabular}{|c|c|c|c|c|}
\hline \multicolumn{5}{|c|}{ Model Summary } \\
\hline Model & $\underline{\mathrm{R}}$ & $\underline{\text { R Square }}$ & Adjusted R Square & $\frac{\text { Std. Error of the }}{\text { Estimate }}$ \\
\hline $\begin{array}{c}1 \\
\text { a. Predic }\end{array}$ & $\begin{array}{l}.129^{\mathrm{a}} \\
\text { (Cons }\end{array}$ & $\mathrm{t}), .017$ & .007 & .250 \\
\hline
\end{tabular}

\section{ANOVA $^{\text {a }}$}


Khaliq \& Zafar / Impact of Dynamic Capabilities on Firm Performance: Moderating Role of Organizational

\begin{tabular}{|c|c|c|c|c|c|c|}
\hline & Model & Sum of Squares & $\underline{\mathrm{df}}$ & Mean Square & $\underline{F}$ & Sig. \\
\hline \multirow[t]{3}{*}{1} & Regression & .108 & 1 & .108 & 1.728 & $.192^{\mathrm{b}}$ \\
\hline & Residual & 6.389 & 102 & .063 & & \\
\hline & Total & 6.497 & 103 & & & \\
\hline \multicolumn{5}{|c|}{ a. Dependent Variable: OP } & & \\
\hline
\end{tabular}

\begin{tabular}{|c|c|c|c|c|c|c|}
\hline \multicolumn{7}{|c|}{ Coefficients $^{\mathrm{a}}$} \\
\hline \multicolumn{2}{|r|}{ Model } & \multicolumn{2}{|c|}{$\frac{\text { Un-standardized }}{\underline{\text { Coefficients }}}$} & \multirow{2}{*}{$\frac{\frac{\text { Standardized }}{\text { Coefficients }}}{\text { Beta }}$} & \multirow[t]{2}{*}{$\underline{\mathrm{t}}$} & \multirow[t]{2}{*}{$\underline{\text { Sig. }}$} \\
\hline & & B & Std. Error & & & \\
\hline 1 & (Constant) & 3.876 & .225 & & 17.223 & .000 \\
\hline & $\mathrm{CC}$ & .072 & .055 & .129 & 1.314 & .192 \\
\hline \multicolumn{7}{|c|}{ a. Dependent Variable: OP } \\
\hline
\end{tabular}

To analyze the influence of Coordinating Capabilities (CC) on Organizational Performance, we use regression analysis. Finding shows that the Organizational Performance is slightly dependent on integrating capabilities of the organization. Table shows that value of $\mathrm{R}$ square is 0.017 for Integrating Capabilities (IC) and Organizational Performance. Hence H 1 (d) hypothesis has also proved.

Regression Analysis for Coordinating Capabilities and Organizational Performance with moderating effect of Organizational Competencies

\begin{tabular}{|c|c|c|c|c|}
\hline \multicolumn{5}{|c|}{ Model Summary } \\
\hline Model & $\underline{\mathrm{R}}$ & R Square & Adjusted R Square & Std. Error of the Estimate \\
\hline 1 & $.337^{\mathrm{a}}$ & .114 & .105 & .238 \\
\hline
\end{tabular}

a. Predictors: (Constant), Interaction4

\begin{tabular}{|c|c|c|c|c|c|c|}
\hline \multicolumn{7}{|c|}{ ANOVA $^{a}$} \\
\hline & Model & $\frac{\text { Sum of }}{\text { Squares }}$ & $\underline{\mathrm{df}}$ & Mean Square & $\underline{F}$ & Sig. \\
\hline 1 & Regression & .739 & 1 & .739 & 13.096 & $.000^{\mathrm{b}}$ \\
\hline & Residual & 5.758 & 102 & .056 & & \\
\hline & Total & 6.497 & 103 & & & \\
\hline
\end{tabular}

a. Dependent Variable: OP

b. Predictors: (Constant), Interaction 4

SIJMB $P$ - ISSN: 2313-1217 E-ISSN: 2410-1885 @ 2015 Sukkur Institute of Business Administration V.2, No.2 |Oct 15 


\begin{tabular}{|c|c|c|c|c|c|c|}
\hline \multicolumn{7}{|c|}{ Coefficients $^{\mathrm{a}}$} \\
\hline \multirow{2}{*}{\multicolumn{2}{|c|}{ Model }} & $\frac{\text { Un-sta }}{\text { Coef }}$ & $\begin{array}{l}\text { ized } \\
\text { ts }\end{array}$ & $\frac{\text { Standardized }}{\text { Coefficients }}$ & $\underline{\mathrm{t}}$ & Sig. \\
\hline & & $\mathrm{B}$ & $\begin{array}{l}\text { Std. } \\
\text { Error }\end{array}$ & Beta & & \\
\hline \multirow[t]{2}{*}{1} & (Constant) & 3.497 & .187 & & 18.665 & .000 \\
\hline & Interaction4 & .041 & .011 & .337 & 3.619 & .000 \\
\hline \multicolumn{7}{|c|}{ a. Dependent Variable: OP } \\
\hline
\end{tabular}

To check the moderating role of organizational competencies between relationship of organizational performance and coordinating capabilities, we add an interaction term and regress it to an organizational performance. Table indicates that organizational competencies do moderates, and positively moderate the relationship between organizational performance and coordinating capabilities. As the value of $\mathrm{R}$ square has increased to 0.114 from 0.017 . Hence $\mathrm{H} 2$ (d) Hypothesis has also proved.

\section{Discussion}

The aim of this study was to determine the relation between dynamic capabilities and performance through the use of large scale survey. The result suggests that there exists the indirect relationship between dynamic capabilities and firm's performance. Dynamic capabilities don't directly create the sustainable competitive advantage, but DC contributes to the firm a superior performance by combining, reallocating and renewing the organizational competencies. So the result posits that dynamic capabilities affect the performance of the firm in both high dynamic or less dynamic environment. According to (Eisenhardt \& Martin, 2000), dynamic capabilities can be operated in high dynamic environment that supports the rapid change (Helfat et al., 2009). So, the managers should always try to advance its competencies in order to seek superior firm performance. They must have to see what competencies that they already have and what competencies they need to create in order to respond to the environment effectively. So, managers should have to invest in dynamic capabilities to enhance the performance of the firm.

\section{Limitations}

The limitations of the study should also be considered when evaluating the findings and implications of the research. Efforts have been made to ensure the data quality, but the survey biases cannot be ignored and excluded. It should be noted that the perception of the respondents may not coincide with the objective and rational reality, which may deviate from the actual or true findings. Furthermore, the cost of creating and incorporating the dynamic capabilities has not been studies which is an issue, as developing and maintain dynamic capabilities in the firm is costly and managers must have to invest keeping in view the budget of the firm, so this is another limitation of SIJMB $P$ - ISSN: 2313-1217 E-ISSN: 2410-1885 (C) 2015 Sukkur Institute of Business Administration V.2, No.2 |Oct 15 
the study. Further research could be done in this regard that covers the cost of developing dynamic capabilities and its benefits for the firm.

\section{Conclusion}

This study determines the relationship between dynamic capabilities and firm performance using organizational competencies as a moderator. Results suggest that source of superior organizational performance lies in relationship between organizational capabilities and organizational competencies. So organizational competencies are the most important variable of the study and study shows that organizations having more competencies can have superior performance. Results also suggest that dynamic capabilities can be operationalize in both high dynamic environment as well as less dynamic environment.

\section{References}

Amit R, S. P. (1993). Strategic assets and organizational rent. . Strategic management journal, 14(1), 33-46.

Barney, J. (1991). Firm resources and sustained competitive advantage. Journal of management, 17(1), 99-120.

Bogner WC, T. H. ( 1994). Core competence and competitive advantage: A model and illustrative evidence from the pharmaceutical industry. In Competence-Based Competition, Hamel G, Heene A (eds.). Wiley: Chichester, 111-143.

Clark, K. B., \& Fujimoto, T. (1991). Product development performance: Strategy, organization, and management in the world auto industry: Harvard Business Press.

Cohen, W. M., \& Levinthal, D. A. (1990). Absorptive capacity: a new perspective on learning and innovation. Administrative science quarterly, 128-152.

Collis, D. J. (1994). Research note: How valuable are organizational capabilities. Strategic management journal, 15(8), 143-152.

D., G. (1988). Managing Quality. Free Press, New York.

D., L.-B. (1995). Wellsprings of Knowledge. Harvard Business School Press: Boston MA.

Danneels, E. (2000). The dynamics of product innovation and firm competences. Paper presented at the Academy of Management Proceedings.

Day, G. S. (1994). The capabilities of market-driven organizations. the Journal of Marketing, 37-52.

Deeds, D. L., DeCarolis, D., \& Coombs, J. (2000). Dynamic capabilities and new product development in high technology ventures: an empirical analysis of new biotechnology firms. Journal of Business venturing, 15(3), 211-229.

Dougherty, D. (1992). Interpretive barriers to successful product innovation in large firms. Organization science, 3(2), 179-202.

Eisenhardt, K. M., \& Martin, J. A. (2000). Dynamic capabilities: what are they? Strategic management journal, 21(10-11), 1105-1121. 
Fowler, S. W., King, A. W., Marsh, S. J., \& Victor, B. (2000). Beyond products: new strategic imperatives for developing competencies in dynamic environments. Journal of Engineering and Technology Management, 17(3), 357-377.

Fredrickson, J. W., \& Mitchell, T. R. (1984). Strategic decision processes: Comprehensiveness and performance in an industry with an unstable environment. Academy of Management journal, 27(2), 399-423.

Galunic, D. C., \& Eisenhardt, K. M. (2001). Architectural innovation and modular corporate forms. Academy of Management journal, 44(6), 1229-1249.

Helfat, C. E. (1997). Know-how and asset complementarity and dynamic capability accumulation: The case of R\&D. Strategic management journal, 18(5), 339360.

Helfat, C. E., Finkelstein, S., Mitchell, W., Peteraf, M., Singh, H., Teece, D., \& Winter, S. G. (2009). Dynamic capabilities: Understanding strategic change in organizations: John Wiley \& Sons.

Helfat, C. E., \& Peteraf, M. A. (2003). The dynamic resource-based view: capability lifecycles. Strategic management journal, 24(10), 997-1010.

Helfat, C. E., \& Raubitschek, R. (2000). Product sequencing: co-evolution of knowledge, capabilities and products. Paper presented at the Tuck-JFE Contemporary Corporate Governance Conference.

Henderson, R., \& Cockburn, I. (1994). Measuring competence? Exploring firm effects in pharmaceutical research. Strategic management journal, 15, 63-63.

Henderson, R. M., \& Clark, K. B. (1990). Architectural innovation: The reconfiguration of existing product technologies and the failure of established firms. Administrative science quarterly, 9-30.

Iansiti, M., \& Clark, K. B. (1994). Integration and dynamic capability: evidence from product development in automobiles and mainframe computers. Industrial and corporate change, 3(3), 557-605.

Kogut, B., \& Zander, U. (1992). Knowledge of the firm, combinative capabilities, and the replication of technology. Organization science, 3(3), 383-397.

March, J. G. (1991). Exploration and exploitation in organizational learning. Organization science, 2(1), 71-87.

Peteraf, M. A. (1993). The cornerstones of competitive advantage: a resource-based view. Strategic management journal, 14(3), 179-191.

Singh, H., \& Zollo, M. (1998). The impact of knowledge codification, experience trajectories and integration strategies on the performance of corporate acquisitions.

Song, M., Droge, C., Hanvanich, S., \& Calantone, R. (2005). Marketing and technology resource complementarity: An analysis of their interaction effect in two environmental contexts. Strategic management journal, 26(3), 259276.

Teece, D. J. (2007). Explicating dynamic capabilities: the nature and microfoundations of (sustainable) enterprise performance. Strategic management journal, 28(13), 1319-1350. 
Teece DJ, P. G., Shuen A. (1997). Dynamic capabilities and strategic management. Strategic management journal, 18(7), 509-533.

Tushman, M. L., \& Anderson, P. (1986). Technological discontinuities and organizational environments. Administrative science quarterly, 439-465.

Wernerfelt, B. (1984). A resource-based view of the firm. Strategic management journal, 5(2), 171-180.

Winter, S. G. (2003). Understanding dynamic capabilities. Strategic management journal, 24(10), 991-995.

Zahra, S. A., Sapienza, H. J., \& Davidsson, P. (2006). Entrepreneurship and dynamic capabilities: a review, model and research agenda*. Journal of Management studies, 43(4), 917-955.

Zollo, M., \& Winter, S. G. (2002). Deliberate learning and the evolution of dynamic capabilities. Organization science, 13(3), 339-351.

Zott, C. (2003). Dynamic capabilities and the emergence of intraindustry differential firm performance: insights from a simulation study. Strategic management journal, 24(2), 97-125. 